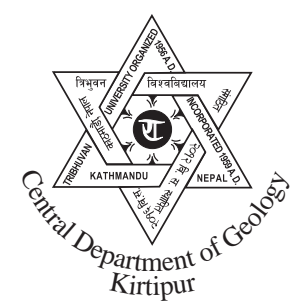

\title{
Alluvial mining and its impact on deterioration of physical health of Malekhu Khola, Central Nepal
}

\author{
*Jharana Khanal \\ Central Department of Geology, Tribhuvan University, Kathmandu, Nepal
}

\begin{abstract}
The Malekhu Khola is accessible and potential for the construction materials in today's developing phase. The study mainly concerns with mining of construction aggregate and effect of indiscriminate mining from river and its basin area which may impose many harmful effects on environment. The objective of the study is to identify the condition of river using morphological and physical parameters, and to investigate the factors which are directly responsible for the environmental degradation. Such study of rivers in present context is essential as it provides insights of strength of the river. To examine the circumstance of river, the study was proceed by selecting the area into three reaches of each $500 \mathrm{~m}$, and further each reaches are divided into six transects. Both reach-scale and transect-scale attributes were assessed. The scoring was done by adding all the attributes of the standard survey sheet. A cross-sectional study was carried out along 3 different stations, Reach 1 to Reach 3 from upstream to downstream. Various fluvial parameters and data from pebble count were used to calculate morphological parameter and grain size distribution. The channel sediments were found to be extremely poorly sorted, the distribution of grain size is varied from transect to transect, which might be the result of unplanned mining. All the result acquired from field study and satellite image confirms that the river is worsening day by day. The formation of pools and deposition of organic matter show that the river is not flowing in its natural way. After all the examination, it indicates that the Malekhu Khola is being violated by the human and mining activities, thus the river reclamation measure is required at abandoned mining sites to maintain the Malekhu Khola channel morphology and habitat of the river.
\end{abstract}

Key words: River mining, Habitat Quality Index, Qualitative Habitat Evaluation Index, central Nepal

Received: 25 June, 2015

Accepted: 15 Aug, 2015

\section{INTRODUCTION}

Mining is becoming theintimate part of the human development. River mining is extensively used because of its easiness for extraction, processing and transportation within thisemerging world. In the mountainous rivers, the extraction activities are growing with the pace of development of engineering infrastructures, urbanization and industrialization (Dahal, 2012). The Malekhu Khola is quite potential for aggregates because it has huge accumulation of gravelly sediments on its channel, bars and banks. Various river reaches have been excavated to collect and transport to

\footnotetext{
*Corresponding author:

E-mail address: khanaljharana77@gmail.com
}

the sites of processing plants established on the terraces. These processing plants of aggregates have been processing and producing aggregates of variable sizes for more than five years. The final products of aggregates are composed of hetero lithic and their quality is of concern to use. Predominantly, the highest extraction of river bed is some few $\mathrm{km}$ upstream from the Malekhu Bazar. This area of the Malekhu Khola is delivered with weighty amount of construction aggregates including sand, cobble, pebbles and boulders.Besides, as the channel and bars have been mined, there is a serious concern on environmental deterioration of the Malekhu Khola.The Malekhu Kholaenvironment is in a humiliatingcondition since the disorganized mining has been conducted. People involving in the mining and processing activities are 
only distresses in the economic sense but the environment of Malekhu Khola is worsening day by day. Many writersare illuminating significance of construction materials and their usage, but there is no any research directed to the impact on river environment and alteration of morphology due to riverbed extraction. Therefore this study inspectsthe situation of morphology and environment due to riverbed extraction in the Malekhu Khola. The overall objective of this study is to measure the impacts of river mining towards morphology and environment. In broad-spectrum study would recommend for the examinations which conforms reason and result connection. Also the study investigates the condition of alteration of river morphology and impact on physical parameter due to indiscriminate riverbed extraction.

Malekhu is a hilly region of central Nepal (Fig. 1). In this area there are mainly two big rivers: the Trishuli River in east and the Buri-Gandaki River in west. The study area has river valley bounded by hills on the either sides of bank. Alongside the river valley, hills show the steep topography on its upstream of the Malekhu Khola with a maximum altitude of about $1500 \mathrm{~m}$ and minimum altitude of $340 \mathrm{~m}$ above the sea level. The Malekhu Khola flowing from the south to the north is contributed by many tributaries.

\section{METHODOLOGY}

The study was carried out in the Malekhu Khola of Nepal in December 2015 in order to assess the impact of river mining using physical and morphological criteria. The reconnaissance survey was carried out along the Malekhu Khola from Malekhu Bazar to upstream. The appropriate three reaches were selected, two in mining site (Reach 2 and Reach 3) and one in non- mining site (Reach 1) (Fig 2a). Each reaches was of $500 \mathrm{~m}$ and is further divided into six transects having equal interval of $100 \mathrm{~m}$ (Fig. 2b). All transects were placed making perpendicular with the stream. Habitat Quality Index based on TNRCC, 1999 was used to find the stream physical characteristics, stream morphology and riparian environment.Qualitative Habitat Evaluation Index Metrics (Ohio EPA, 2006) method was accepted to assess the habitat in the flowing water.Cross sectional survey was arranged in order to

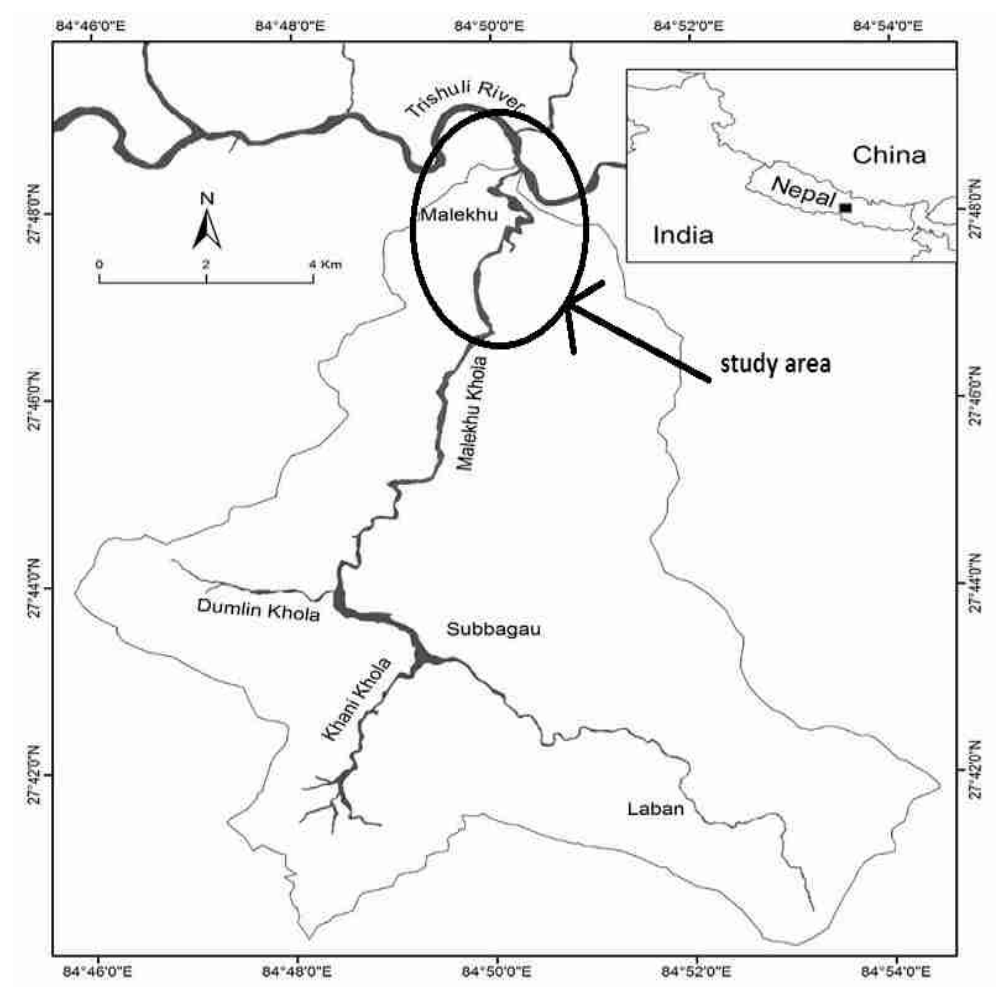

Fig. 1 Location map of the study area 

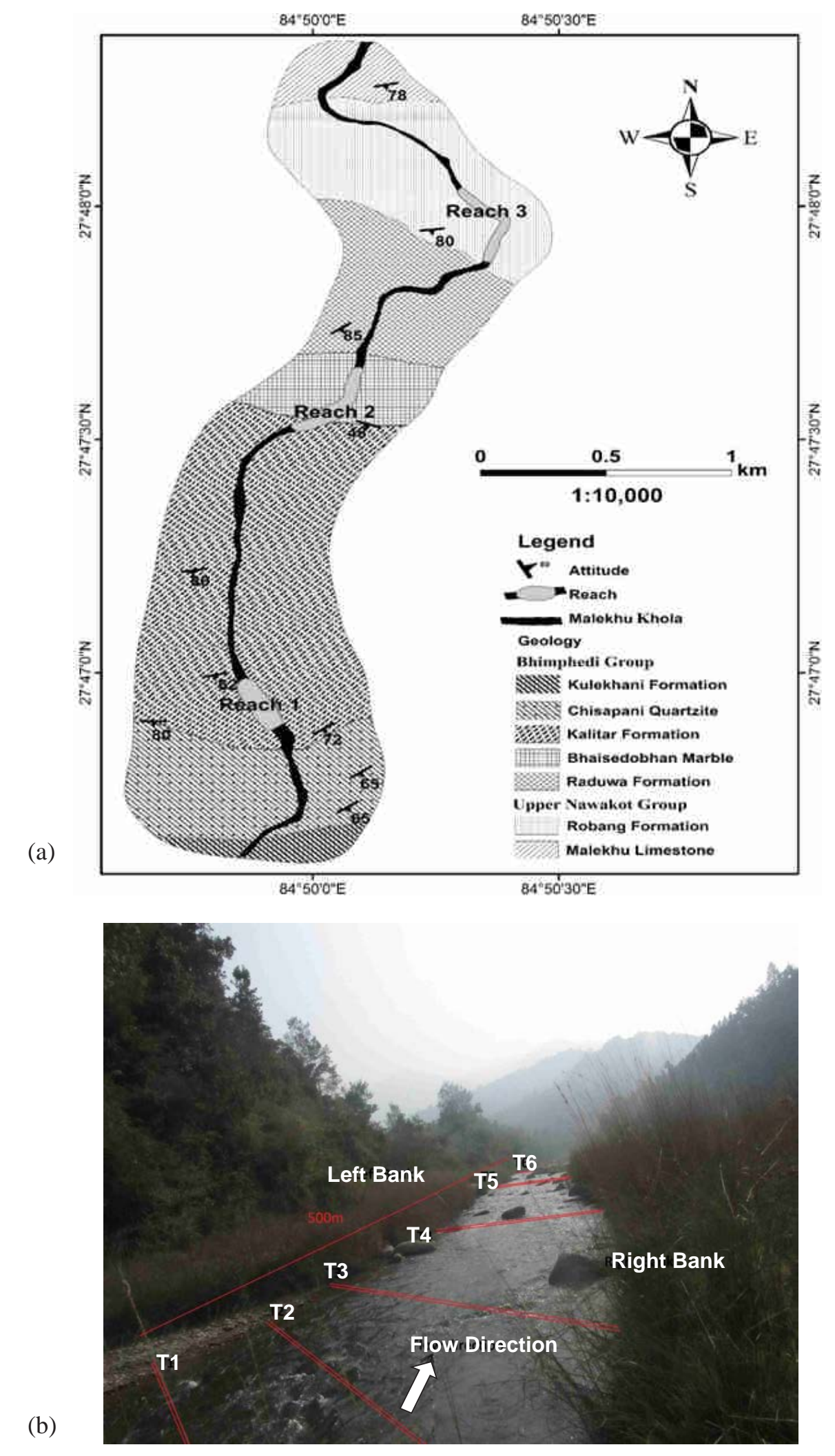

Fig. 2 (a) A geological map of the study area showing selected reaches, and (b) Photograph showing reach and transects 
find the morpho-hydrological parameters. Grain size distribution analysis (Wolman, 1954) was held to obtain the dominant grain size which are transported and deposited by the river and value varies according to stream dynamics of the river. Satellite image study was also furnished to compare the alteration of river morphology before and after the establishment of crusher plant.

\section{RESULTS}

The different parameters calculated throughout this research are defined below in corresponding sections.

\section{Habitat Quality Index (HQI)}

Habitat Quality Index (HQI) score shows the variation in data of the Reach 1, Reach 2 and Reach 3. Available instream cover, bottom substrate stability, riparian vegetation and aesthetic of reach play the most important role to fluctuate the total score (Table 1). The Reach 1 has highest value than that of Reach 2 and Reach 3 where the scores of each are 22, 18 and 19 respectively out of 31 . The highest the score of stream habitat assessment the condition of river is more natural (TNRCC, 1999), this clearly shows that the Reach 1 or the non-mining site is more unaffected by mining and other anthropological effects in the Malekhu Khola.

\section{Qualitative Habitat Evaluation Index (QHEI)}

Another method, QHEI also shows the great deviation in six matrices including all the parameters. The substrate type, functional riffle, instream type, bank erosion and riparian zone are accountable for oscillation of scores (Table 2). Reach 1 has the highest value of 57.5 with narrative ratings fair whereas the reach 2 has lowest value 44 and reach 3 scores 51.5 with narrative ratings poor and fair respectively. Here also the Reach 1 or the non-mining sites have highest scores rather than others. Which means the river condition is better than the other mining site (Ohio EPA, 2006). The reach 1 (non-mining site) also notch the subordinate value here out of 100 because not only the human activities and extraction of riverbed material are blamable for the depreciation of river environment but also the river itself have some exertion. Erosion of loose sediments and undercutting of bank are triggered by high velocity

Table 1: Tabulation of HQI values of Reach 1, Reach 2 and Reach 3

\begin{tabular}{|c|c|c|c|c|c|}
\hline \multirow[b]{2}{*}{ Attributes } & \multirow[b]{2}{*}{ Habitat Parameter } & & \multicolumn{3}{|c|}{ Habitat Quality Index Score } \\
\hline & & & Reach -1 & Reach-2 & Reach-3 \\
\hline \multirow[t]{8}{*}{ Primary } & Available Instream Cover & category & abundant & common & rare \\
\hline & & Score & 4 & 3 & 2 \\
\hline & Bottom substrate stability & category & stable & Mod. stable & Mod. unstable \\
\hline & & Score & 4 & 3 & 2 \\
\hline & Number or riffles & category & abundant & abundant & abundant \\
\hline & & Score & 4 & 4 & 4 \\
\hline & Dimension of largest pool & category & small & small & small \\
\hline & & Score & 2 & 2 & 2 \\
\hline \multirow[t]{6}{*}{ Secondary } & Channel Flow status & category & low & moderate & moderate \\
\hline & & Score & 1 & 2 & 2 \\
\hline & Bank Stability & category & Mod. unstable & Mod. unstable & Mod. unstable \\
\hline & & Score & 1 & 1 & 1 \\
\hline & Channel Sinuosity & category & moderate & moderate & moderate \\
\hline & & Score & 2 & 2 & 2 \\
\hline \multirow[t]{5}{*}{ Tertiary } & Riparian Buffer vegetation & category & wide & moderate & wide \\
\hline & & Score & 2 & 1 & 2 \\
\hline & Asthetics of Reach & category & natural area & offensive & natural area \\
\hline & & Score & 2 & 0 & 2 \\
\hline & Total Score & & 22 & 18 & 19 \\
\hline
\end{tabular}


of water which deflects the score of physical habitat. The pasture lands, offensive environment, narrow riparian zone and bank erosion potential also liable for the poor ratings.

\section{pH and Electrical Conductivity (EC) Value}

The $\mathrm{pH}$ measures the alkalinity presence in the water. The river water was alkaline although it varied from transect to transect. The average $\mathrm{pH}$ in the Malekhu Khola during study conducted was 7.6 where Reach 3 has got highest value of $\mathrm{pH}$. The value steadily increases towards the downstream portion (Fig. 3). Calcium carbonate $\left(\mathrm{CaCO}_{3}\right)$ and other bicarbonates can combine with both hydrogen or hydroxyl ions to neutralize $\mathrm{pH}$, thus the alkalinity of a stream or other body of water is increased by carbonate-rich soils (carbonates and bicarbonates) such as limestone, dolomite etc. So the growing value of $\mathrm{pH}$ towards downstream shows the signal of presence of high carbonate content in the water.

EC usually signifies to the amount of salt concentration in the water (Laluraj and Gopinath, 2006) and it can be determined by several dissolved constituents. The greateramount of dissolved solid in river water indicates the greater value of ions in the same water. In the Malekhu Khola, highest EC were noted in Reach 3 than that of Reach 2 and Reach 1, wherever there might be the higher concentration of salt minerals is present in the Reach 3, and also might be

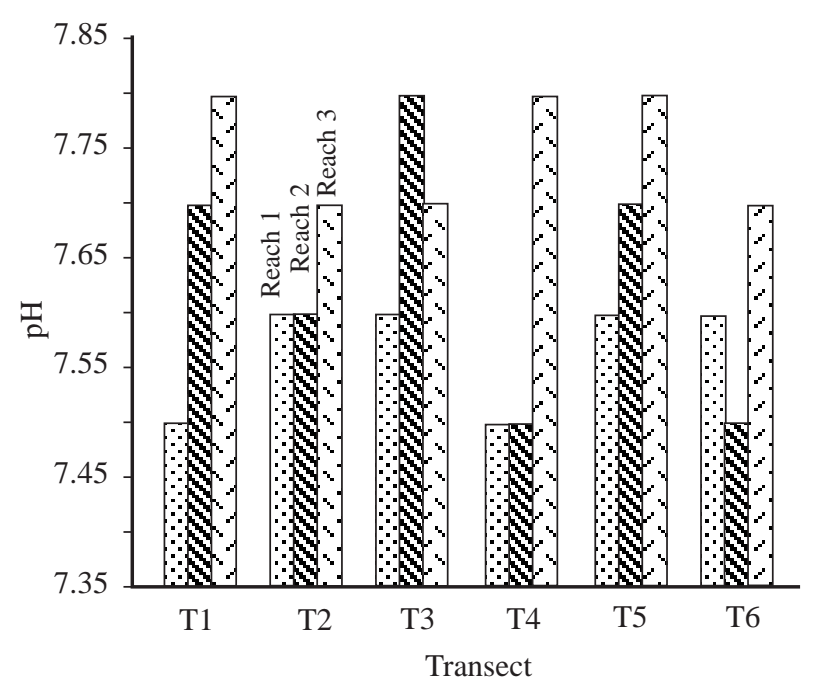

Fig. $3 \mathrm{pH}$ value of the Malekhu Khola there is a problem of riverbed extraction. In addition, the study area receive excessive amount of organic matter compared to the upper reaches. Increasing of EC values gradually towards downstream or towards the mining site is an indication of river contamination as related to the previous reaches (Fig. 4).

Table 2: Score obtained of QHEI in the Reach 1, Reach 2 and Reach 3

Reach $1 \quad$ Reach $2 \quad$ Reach 3

\section{Substrate}

Best types

other types

origin

quality

$\begin{array}{ccc}8 & 8 & 8 \\ 2 & 2 & 2 \\ 0 & 0 & 0 \\ 0 & -4 & -2 \\ \mathbf{1 0} & \mathbf{6} & \mathbf{8}\end{array}$

\section{Instream Cover}

Undercut banks

boulders

aquatic macrophytes

amount

$\begin{array}{ccc}2 & 2 & 2 \\ 1 & 2 & 3 \\ 1 & 1 & 1 \\ 7 & 7 & 7 \\ \mathbf{1 1} & \mathbf{1 2} & \mathbf{1 3}\end{array}$

\section{Channel Morphology}

sinuosity

Development

channelization

stability

\section{Bank Erosion - Riparian Zone}

Erosion
riparian width
Flood plain quality

\section{Pool/Glide and} riffle/run quality

maximum depth

channel width

current velocity

Riffle depth

run depth

riffle/run substrate

riffle/run embeddedness

\section{Gradient}

Total score

$\begin{array}{ccc}2.5 & 2 & 1.5 \\ 2.5 & 2.5 & 2.5 \\ 1.5 & 1.5 & 1.5 \\ \mathbf{6 . 5} & \mathbf{6} & \mathbf{5 . 5}\end{array}$




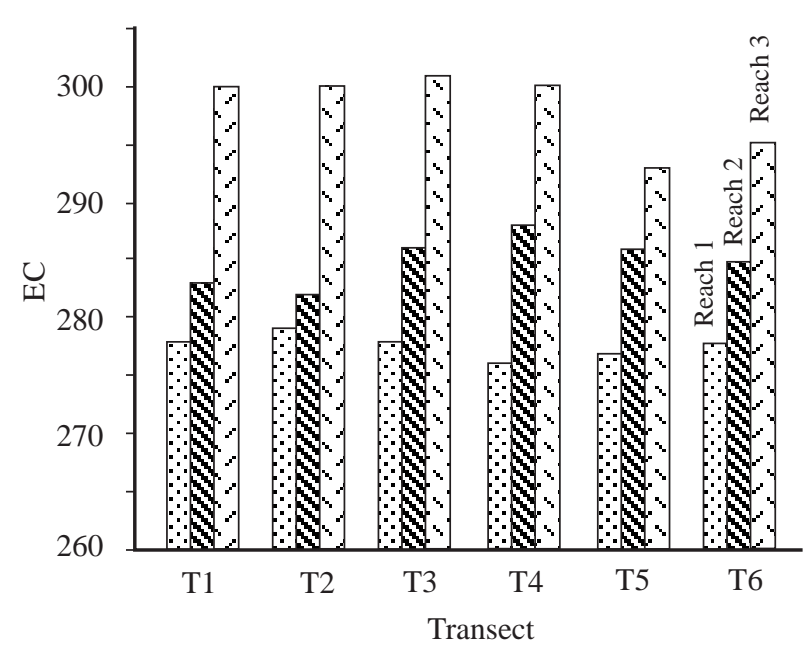

Fig. 4 EC value of the Malekhu Khola

\section{Morpho- hydrological data}

Morpho-hydrologic parameters involve morphologic analysis of watersheds which includes the quantification of the channel network and related parameters such as drainage area, gradient and relief which play vital role for understanding the geohydrological behavior of drainage basin and express the prevailing climate, geology, geomorphology, structure etc. Morphological data were derived using dimensional cross sectional analysis of stream sediment and measurement from topo-map, 1:25000.The different morphological parameters such as width/depth ratio, entrenchment ratio, bankfull cross section area, flood prone area were calculated to know the morphology of Malekhu River based on Rosgen 1994. The width depth ratio is highest (60.50) in the third transect of Reach 3, which shows it is prone for the near bank erosion (Table 3 ). The entrenchment ratio is highest in the 4 th transect of Reach 4 which shows the high affinity of flooding. There is no linear pattern in the variability of morphological parameters. The study shows contrast between the data of different transects in a same reach. In a normal condition of river, the entrenchment ratio generally increases towards downstream of the river. But in the study area, coming towards downstream from the Reach 1 to Reach 3 there is no such indications of increase in the ratio but data obtained are randomly so it can be concluded that the extraction here is doing haphazardly.

\section{Grain Size Distribution}

Generally upstream portion of the river consists of large sized boulders and the Malekhu Khola also tracks the same pattern in upstream area (Magar, 2015). It consists of large boulders of granite which were as much as $3.5 \mathrm{~m}$ (b-axis). But coming towards downstream it does not trails the same pattern, big boulder present in the area suddenly followed by the silt and clay presenting drastic change in grain size distribution. The value of $D_{50}$ almost lies within $16 \mathrm{~mm}$

Table 3: Morphological data of the Malekhu Khola

\begin{tabular}{|c|c|c|c|c|c|c|c|c|c|c|c|c|}
\hline \multirow{2}{*}{$\begin{array}{c}\text { Morphological data } \\
\text { Transect } \\
\end{array}$} & \multicolumn{6}{|c|}{ Reach-3 } & \multicolumn{6}{|c|}{ Reach -2} \\
\hline & $\mathrm{T} 1$ & $\mathrm{~T} 2$ & T3 & $\mathrm{T} 4$ & $\mathrm{~T} 5$ & T6 & $\mathrm{T} 1$ & $\mathrm{~T} 2$ & T3 & $\mathrm{T} 4$ & T5 & T6 \\
\hline Width at bankfull, $\mathrm{W}_{\text {bkf }}(\mathrm{m})$ & 20 & 20 & 22 & 17 & 26 & 22 & 22 & 20 & 29 & 23 & 9.5 & 21 \\
\hline Width Floodprone area, $\mathrm{W}_{\mathrm{fpa}}(\mathrm{m})$ & 30 & 27 & 28 & 19 & 35 & 27 & 32 & 22 & 46 & 38 & 13 & 26 \\
\hline Bankfull X-section area, $\mathrm{A}_{\mathrm{bkf}}\left(\mathrm{m}^{2}\right)$ & 21 & 12 & 8 & 9 & 26 & 26 & 24 & 22 & 23 & 17 & 4.5 & 6.2 \\
\hline Max. depth bankfull, $\mathrm{D}_{\max }(\mathrm{m})$ & 2.8 & 1.2 & 1.3 & 0.8 & 1.2 & 1.5 & 1.4 & 1.5 & 0.9 & 1.1 & 0.8 & 0.7 \\
\hline Mean depth at bankfull, $\mathrm{D}_{\mathrm{bkf}}=\mathrm{A}_{\mathrm{bkf}} / \mathrm{W}_{\mathrm{bkf}}(\mathrm{m})$ & 1.1 & 0.6 & 0.4 & 0.5 & 1 & 1.2 & 1.1 & 1.1 & 0.8 & 0.8 & 0.5 & 0.3 \\
\hline Max. depth ratio, $D_{\max } / D_{\text {bkf }}$ & 2.6 & 2 & 3.6 & 1.5 & 1.2 & 1.3 & 1.3 & 1.4 & 1.1 & 1.5 & 1.7 & 2.4 \\
\hline Width/depth ratio, W/D $=\mathrm{W}_{\mathrm{bkf}} / \mathrm{D}_{\mathrm{bkf}}$ & 18 & 33 & 61 & 32 & 26 & 18 & 20 & 19 & 36 & 30 & 20 & 71 \\
\hline Entrenchment ratio, $\mathrm{ER}=\mathrm{W}_{\mathrm{fpa}} / \mathrm{W}_{\mathrm{bkf}}$ & 1.5 & 1.4 & 1.3 & 1.1 & 1.3 & 1.2 & 1.5 & 1.1 & 1.6 & 1.7 & 1.4 & 1.2 \\
\hline
\end{tabular}


to $64 \mathrm{~mm}$ for the Malekhu Khola. Hence, the Malekhu Khola is called a gravel bed stream. But there are abnormal values in some transects, 5 th and 6 th transects of reach 2 have the value of $D_{50}$ greater than $64 \mathrm{~mm}$ that means these transects have boulder to cobble sized sediments rest over the river banks and channels which are difficult to transport for crusher plant. The fourth transect of Reach 2 have $D_{50}$ value 0.25 which belongs to the medium sand particles, settled in the bottom after the extraction of gravel (Fig. 5). The high instability of data in a same reach within $500 \mathrm{~m}$ noticeably proves that the extraction of river sediments is going unsystematically.

\section{Satellite Image}

Study of satellite image clearly shows the evidence of change in river morphology throughout the certain time span. The satellite image from 2002, before the establishment of processing plant verifies that there is a vibrant bifurcated river channel at Reach 3 of the Malekhu Khola (Fig. 6). The accumulation of river sediments is naturally stratified. The channel was not blocked by the river sediments whereas in the image of 2014 the bifurcated river channel is almost collapsed, sediments are erratically disperses. Bigger sediments themselves are hindering the path of river which finally leads the alteration of channel.

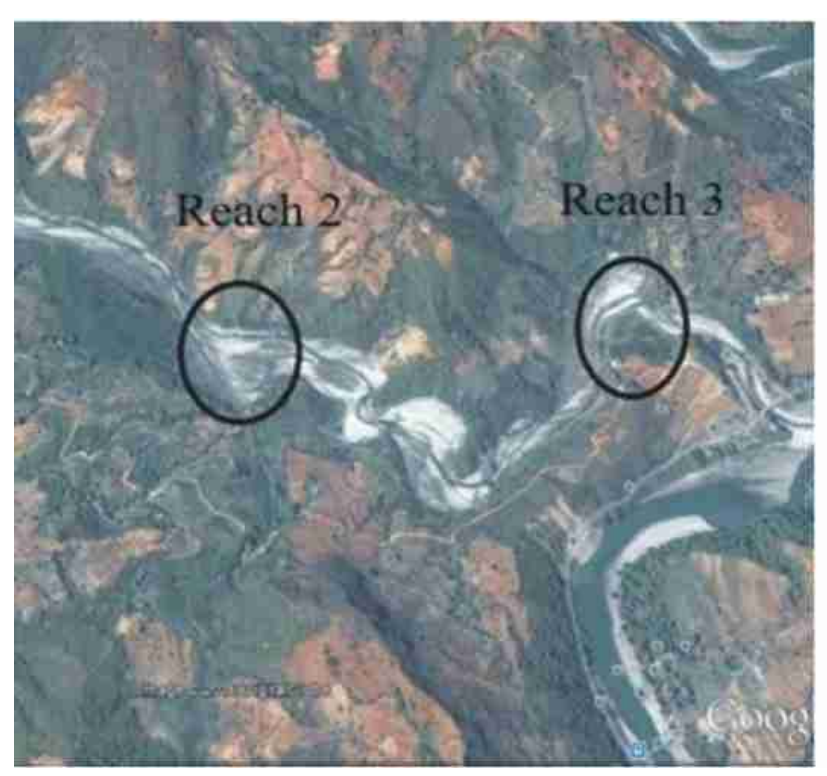

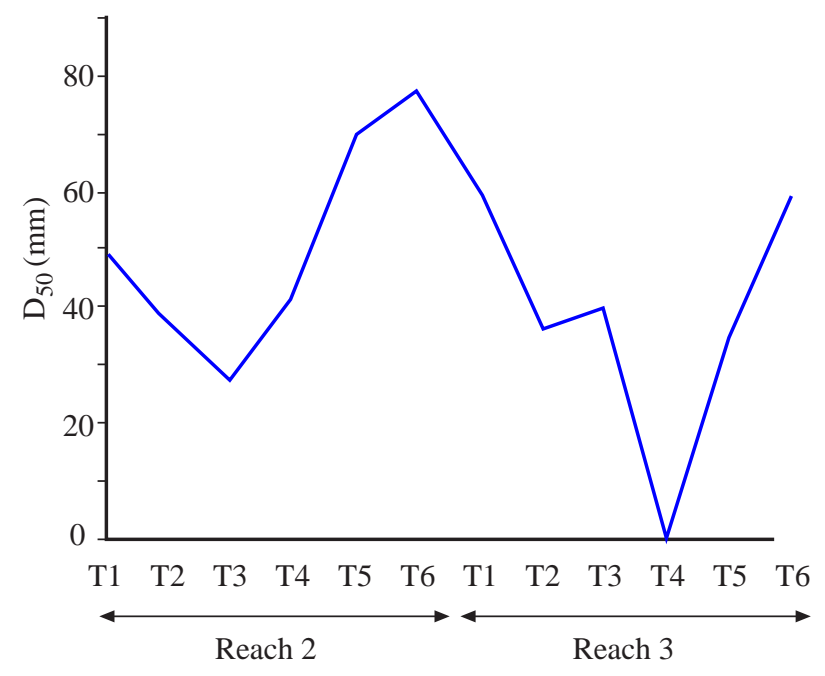

Fig. 5 Graph showing fluctuation of $\mathrm{D}_{50}$ in different transect

The removal of soil, extraction of sand from instream bed and flood plain are highly adopted in the study area where oversized materials are accumulated in the stream channel as well as in the bank side. These oversized unfed material in the channel and bar blocks the flow of water and finally leads the alteration of channel. The extraction of sediments below the depth of Dmax in reach 2 and 3 are very common which further makes the pool. The contaminated pool with silt, clay, organic matter and mycrophytes are clearly observed in reach 3 (Fig. 7).

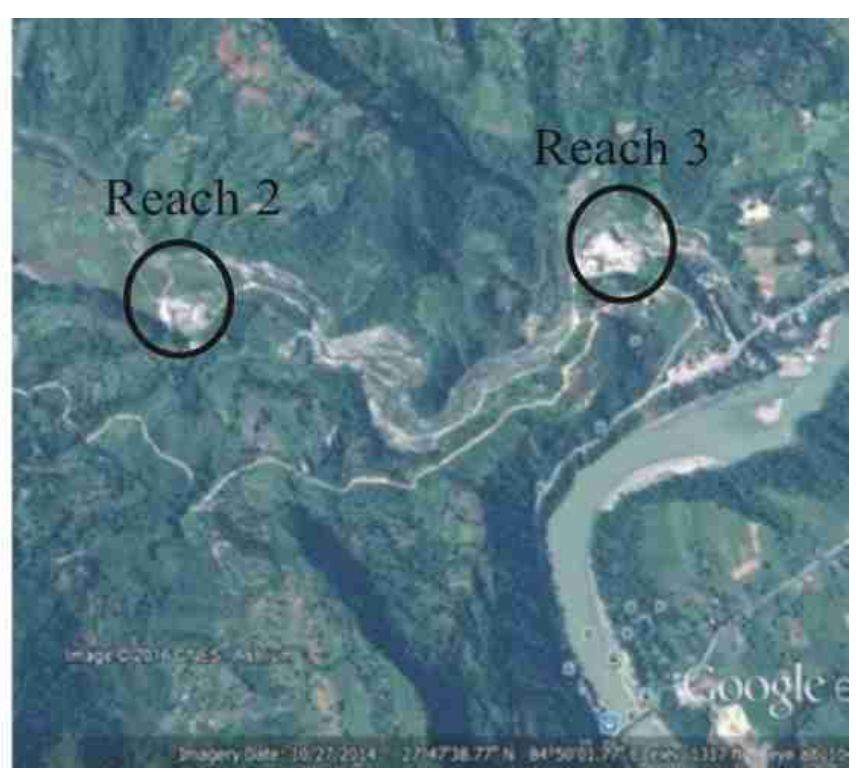

Fig. 6 Satellite image of year 2002 (left) and 2014 (right) of the Malekhu Khola 

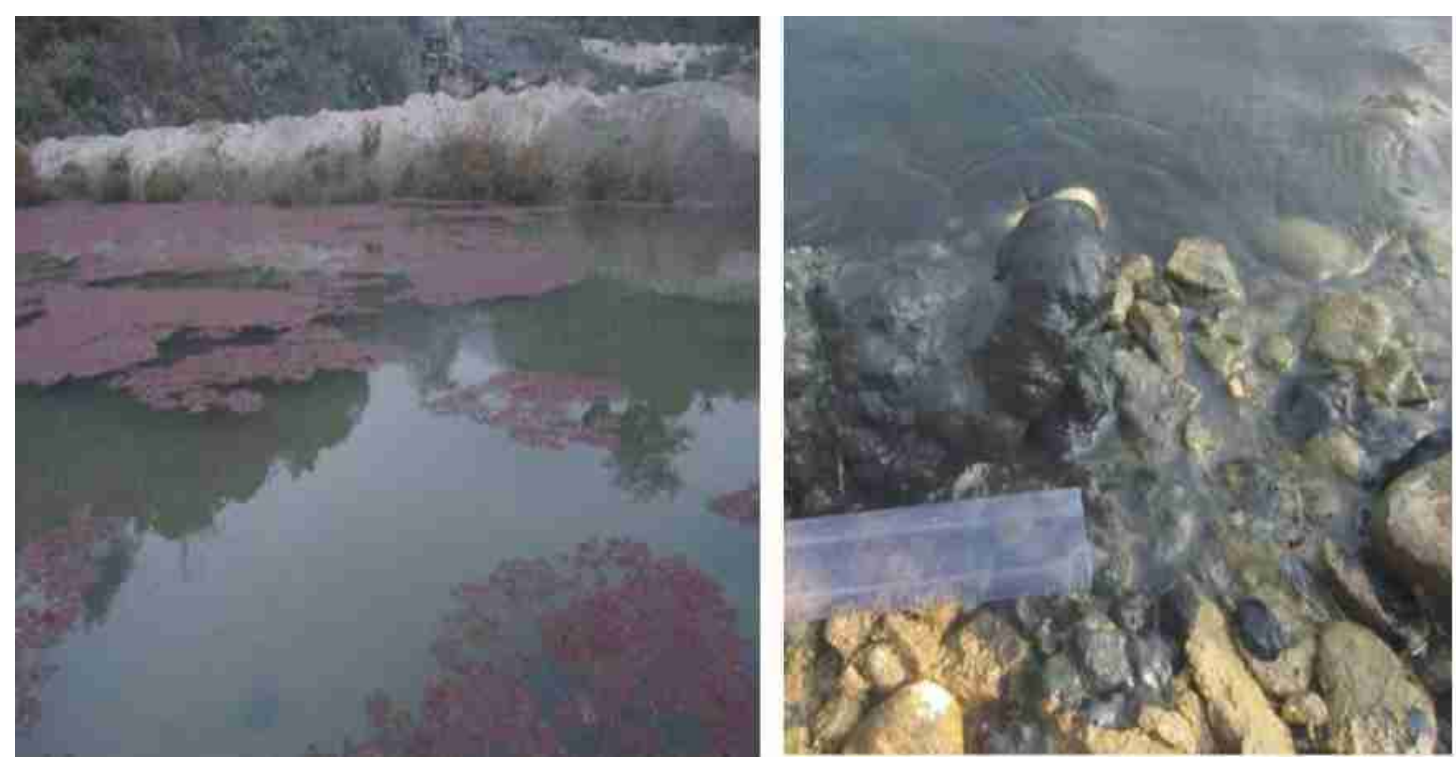

Fig. 7 Contaminated pool and organic matter around Reach 3

\section{CONCLUSIONS}

The Malekhu Khola has huge potential for the accumulation of sediments in the rainy season, which is main source of construction aggregates. River morphology and habitat of the Malekhu Khola is deteriorated due to unplanned and haphazard mining. The data obtained from the habitat assessment (both HQI and QHEI), EC and $\mathrm{pH}$ values, morphological parameters, grain size distribution and satellite image shows that the river has been more affected in the mining site rather than in the non-mining site. Variation in these all parameter indicates that the riverbed excavation process is not uniform. The extreme deviation in the data is the result of disordered mining activities. Sorting and size of channel sediment is affected by the human influences and extraction of bed material from river, that means the extraction activity is against the rules and regulations of government of Nepal. To prevent the encroachment in the natural stream, it is necessary to follow the rules and regulations of river mining, and mining should be trailed byreclamation. It is recommended not to mine directly from the river channel, but to localize on the older floodplains and terraces located some distance away from the channel, so as to maintain vegetative buffer zone of the channel.

\section{REFERENCES}

Dahal, K.R., Sharma, S., Sharma, C.M., and Bajracharya, R.M., 2012. Effects of riverbed extraction on physicochemical parameters of Tinau River, Nepal. International Journal of Development and Sustainability, v. 1, pp 255-267.

Laluraj, C.M., and Gopinath, G., 2006. Assessment of seasonal variation of groundwater quality of Phreatic aquifer - A river basin system, Environmental Monitoring and Assessment, v. 117, pp. 45-57. https://doi.org/10.1007/s 10661-006-7675-5

Magar, M., 2015.Recent fluvial system and sediment characteristics of the Malekhu River, Central Nepal, pp 19-31.

Ohio EPA, 2006. Methods for assessing habitat in flowing waters: using the qualitative habitat evaluation index (QHEI). Technical Bulletin EAS/2006-06-1. Revised by the Midwest Biodiversity Institute.

Rosgen, D.L., 1996. Applied River Morphology. Wildland Hydrology, Pagosa Springs, CO.

TNRCC, 1999.Surface water quality monitoring procedures manual. Report GI 252.Texas Natural Resource Conservation Commission, Austin Texas.

Wolman, M.G., 1954. A method of sampling coarse riverbeds material. Trans. Am. Geophysics, Union, v. 35, pp. 951-956. https://doi.org/10.1029/TR035i006p00951 